\title{
Genealogy, Virality, and Potentiality: Moving Beyond Orientalism with COVID-19
}

\author{
Eben Kirksey $\mathbb{D}$
}

Received: 16 June 2020 / Accepted: 24 February 2021 / Published online: 10 September 2021

(C) Journal of Bioethical Inquiry Pty Ltd. 2021

\begin{abstract}
Stereotypes about exotic peoples and animals of the Orient shaped popular origin stories about COVID-19 in media reports. Outbreak narratives centred on the seafood market in Wuhan began to fall apart as new evidence was published by medical doctors, virologists, and epidemiologists. No viruses in bats or pangolins have been found that are direct ancestors of SARS-CoV2, the virus responsible for COVID-19 symptoms. Viruses are also being transformed as they interact with the human institutions, infrastructures and behaviours that facilitate their spread. Epidemiological growth curves are shaped by national and foreign capital, cosmopolitanism, aspirations for independence and ongoing interdependence, the discourse of power and the discourse of resistance, as well as coexistence and violence. In reckoning with SARS-CoV2, we need to anticipate disruptive surprise of viral emergence rather recursively search for origins. Departing from Foucault's foundational insights, this article gestures towards genealogies of possible viral futures.
\end{abstract}

Keywords Multispecies studies · COVID-19. Emergence $\cdot$ China $\cdot$ Orientalism

E. Kirksey $(\bowtie)$

Deakin University, Building IC, Level 1 Faculty of Arts and Education, 75 Pigdons Road, Waurn Ponds, VIC 3216, Australia e-mail: eben.kirksey@deakin.edu.au

\section{Genealogy, Virality, and Potentiality: Moving Beyond Orientalism with SARS-CoV-2}

When local officials in the Wuhan province of China announced the emergence of a novel coronavirus on New Year's Eve 2019, they speculated about its origin: "there has been a cluster of viral pneumonia cases in the city, some of which had been linked to the seafood market, which also sells live animals" (Zhuang et al. 2020, I15). As the international media slowly picked up on the story, it seemed like the virus would be confined to east Asia. Early outbreak narratives reinforced the fundamental ontological and epistemological distinction-first identified by Edward Said (1979)_between "the Orient" and "the Occident." An exotic animal market, deep in the inscrutable East, spawned a deadly new virus. Initially, it seemed like Europe and the United States would not be seriously impacted. Foundational distinctions of Orientalism-separating the healthy from the sick, the normal from the perverse, the civilized from the savages-seemed to be staying in place (cf. Clifford 1980).

A video produced by Vox Atlas-which garnered over 22 million views on YouTube-dramatizes origin stories about SARS-CoV-2 against the backdrop of an ominous sound track. ${ }^{1}$ Animated graphics offer a secular morality tale. We encounter the full molecular structure of the virus-rendered in colour with

1 https://www.vox.com/videos/2020/3/6/21168006/coronavirus-covid19-china-pandemic 
three dimensions-before there is a quick jump in scale and perspective to planet earth. Playing with "the god-trick of seeing everything from nowhere" (Haraway 1988: 176), visualizing technologies zoom down to the continent of Asia, then to a satellite picture of the Wuhan market. The narrator asks: "What do these markets have to do with the Coronavirus outbreak? Why is it happening in China?" Like other outbreak narratives, this video stigmatizes "individuals, groups, populations, locales (regional and global), behaviors, and lifestyles" (Wald 2008, 3). A close reading of this Vox video offers an opportunity to reflect on how many media outlets reanimated old stereotypes about Asian people and their entanglements with exotic animals during their initial coverage of the coronavirus outbreak.

The Wuhan market was depicted by Vox as a dangerous contact zone, where surprising multispecies encounters produced the emergence of a new virus (cf. Pratt 1992; Haraway 2008). Simple cartoons illustrate the presumed transmission pathway. "There is some evidence that it went from a bat to a pangolin before infecting a human," says the narrator. The video then cuts to gory scenes from markets in mainland China. A limp mallard duck is dismembered on a butcher's block, then the camera pans by food stalls with raw meat hanging from hooks. An expert chimes in: "It was not a surprise to many scientists. The cages are stacked one over another. Animals at the bottom are often soaked with all kinds of liquid. Animal excrement, pus, blood."

The expert in the Vox video, Peter Li-an Associate Professor at the University of Houston, Downtown-is not an epidemiologist or virologist, but a political scientist. Li offers an insightful analysis of the political and economic dynamics of the live animal trade in China-charting the emergence of industrial wildlife farms backed by the Chinese Communist Party. Li describes how small-scale farming ventures were quickly scaled up with the influx of capital, producing animal welfare problems and opportunities for the endangered species trade. Rather than blame the Chinese populace as a whole for this bestial morass, Li suggests that China's wildlife farming industry has promoted lax regulations with their "enormous lobbying capability." But, then Vox leaps to some hasty conclusions. They suggest: elite Chinese who drive the endangered species trade have exposed the world to a viral pandemic.
This outbreak narrative has traces of enduring stereotypes about the Orient: teeming exotic marketplaces and corrupt officials have threatened civilization itself. The people and animals who feature in the story, to reference Said, share "in common an identity best described as lamentably alien" (1979, 207). With subtle visual cues, and a selective presentation of the available evidence, Vox fed Donald Trump's stigmatizing rhetoric about the "Chinese virus."

Origin stories that centre on the seafood market in Wuhan began to fall apart in January 2020 as medical doctors, virologists and epidemiologists published new evidence. Jon Cohen, a journalist who writes for Science, was among the first people to challenge the wet market outbreak narrative. On January 26th Cohen suggested that "the virus possibly spread silently between people in Wuhan - and perhaps elsewhere-before the cluster of cases from the city's now-infamous Huanan Seafood Wholesale Market was discovered" (Cohen 2020, II4).

One key bit of evidence for this counter-narrative is buried in The Lancet, a world-renowned medical journal. The team of Chinese physicians who studied the initial COVID-19 patients found that the first reported cases did not involve contact with exotic animals (Huang et al. 2020). Patient zero in this study was someone who never visited the market and began experiencing symptoms on December 1, 2019. Nine days later, two other people who had no known contact with the market experienced the onset of symptoms. On that same day, December 10, the first patient who had visited the seafood market also became sick.

A definitive origin story of SARS-CoV-2 may never be told. Genetic data suggests "no animal coronavirus has been identified that is sufficiently similar to have served as the direct progenitors of SARS$\mathrm{CoV}-2$, the diversity of coronaviruses in bats and other species is massively undersampled" (Andersen et al. 2020, 2). In other words, early reports about pangolin and bat coronaviruses may have been simply an artefact of sampling. Scientists were looking for coronaviruses in exotic animals, and they found them. A year and a half later, an article published by Nature reported that no pangolins or bats were actually traded in Wuhan's markets, supporting reformed opinion that they were not "the source of the current coronavirus (COVID-19) pandemic" (Xiao et al. 2021, 1). 
Early sampling efforts diverted the attention of the public and policymakers away from industrial and agricultural assemblages. The proximity of thousands of genetically similar animals in industrial farms has contributed to previous viral emergences-like H1N1 influenza (Lowe 2010). Hogs on farms in China have tested positive for SARS (Chen 2005), and industrial pork facilities in the United States have been home to outbreaks of distantly related coronavirus strains (Blanchette 2015).

The genealogical project of Michel Foucault aimed "to dispel the chimeras of the origin" $(1977,144)$. Instead of searching for origins, Foucault worked to uncover moments of "emergence"- the accidents that accompany every beginning, the contingencies that produce the surprising jolts of history. But, the philosopher who gave us the ideas of biopower and biopolitics, explicitly disavowed genealogical methods in the study of life itself: "Genealogy does not resemble the evolution of a species," writes Foucault, "and does not map a destiny of a people" (146). On the contrary, the genealogical method seeks to identify "the minute deviations-or conversely, the complete reversals - the errors, the false appraisals, and the faulty calculations that gave birth to those things that continue to exist" $(1977,146)$.

Genealogical methods in the biological sciences have matured since the time of Foucault. The advent of high throughput whole genome sequencing technologies, and the associated development of bioinformatics programs to reckon with huge genomic datasets, have enabled evolutionary biologists and taxonomists to intensively study the minute deviations, the mutations and surprising accidents, that produce emergent forms of life. In times of great planetary trouble, critical friendships are bringing biological scientists together with influential cultural theorists (Reardon et al. 2015; Haraway 2016). Hybrid transdisciplinary perspectives have enabled us to study emergent ecological communities where species have materialized within faults and fissures between established assemblages (Kirksey 2015).

Earlier viral epidemics have been carefully studied as products of epidemiology, genealogy, and history (Lowe 2010; Porter 2019; Keck 2020). Situated multispecies studies of the SARS-CoV-2 virus, and the associated COVID-19 symptoms, have just begun. Viral genealogists who have closely studied the emergence of this virus have not found a clear evolutionary tree sprouting from a single trunk. Instead, they have found a tangled web of relations, with jumping genes that make viral strains difficult to classify, categorize, and sort (cf. Helmreich 2003). One key paper in Nature found evidence that "genome fragments derived from multiple SARS-CoV related lineages" had recombined in multiple animal hosts, creating the conditions of possibility for the emergent pandemic (Lam 2020, 2). Rather than look for a single point of viral origin, now leading microbiologists are studying the possibility of "many prior zoonotic events" where coronaviruses were passed back-andforth between humans and multiple animal species (see Kirksey 2020).

In reckoning with SARS-CoV-2, a narrowly construed molecular genealogy would lead us away from the institutions, imaginaries, desires, and vectors that have shaped the pandemic. We urgently need new empirical research in multispecies ethnography-that brings together interdisciplinary knowledge about virology, ecology, molecular biology, the veterinary sciences, together with insights from cultural studies, philosophy, architecture, and design-to understand the emergence of SARS-CoV-2.

Viruses live in ecological communities. As they are exchanged between different kinds of hosts, viruses are constantly becoming-beside-themselves as they interact with different immune systems and molecular receptors (cf. Rotman 2008). These microbes are also being transformed as they interact with the human institutions, infrastructures and behaviours that facilitate their spread (Lowe 2010). We now live in an era when viral epidemiology is shaped by national and foreign capital, cosmopolitanism, aspirations for independence and ongoing interdependence, the discourse of power and the discourse of resistance, as well as coexistence and violence (cf. Benitez-Rojo 1985).

Power inequalities among people shaped the contours of the coronavirus outbreak. Before the pandemic, only some people had the freedom to travel. The virus found an exploit in the transportation infrastructure that catered to the cosmopolitan elite. Fleet footed humans, not animals, became the primary hosts and vectors as the virus used us to jump scales, going global. Airports, international flight paths, and global transportation hubs enabled a local outbreak to 
become a pandemic. Feeble biosecurity measures at borders, failed to control the spread.

The virus exposed asymmetries of responsibility and vulnerability in the modern world system. As it swept through prisons, through refugee detention centres, through communities where people could not afford to socially isolate, causalities fell along lines marked by social class and race. As people of privilege sheltered in place, essential workers in the global supply chain succumbed to the virus-laying bare ongoing relationships of dependence, exploitation, and inequality.

If Orientalism was once a stable "Western style for dominating, restructuring, and having authority over the Orient" (Said 1979, 3), the coronavirus pandemic revealed deep cracks in the architecture of Western hegemony. After South Korea, Singapore, and China took swift and effective action to limit viral transmission, the world watched in horror as patients died in hospital hallways in Italy. The virus inspired ironic commentary about American exceptionalism, when Hillary Clinton tweeted "He did promise "America First," as the United States became a world leader with the largest number of COVID-19 patients and deaths. The viral pandemic exposed the failing national and imperial projects of the United States and Europe but also the rising influence of East Asia in techno-science and other domains of soft power.

A few years before the pandemic, in October 2017, China's President Xi Jinping consolidated his grip on the country and announced his plans for the future with his signature China Dream speech. The aspirations of $\mathrm{Xi}$ were heterogeneous and multiple- a fusion of neo-liberal capitalism with Marxism, visions of a techno-scientific future wedded to a broad programme of "material, political, cultural and ethical, social, and ecological advancement" (Xi 2017). Critics were quick to take aim at Xi's rhetoric, for trying to "align the dreams of the 'people' with the nation's march toward a political, economic, and even military revival" (Yang 2017, 205). At the same time, in the domain of Chinese cultural production, more subtle projects were underway that celebrated multiplicity in the face of hegemony. Chinese artists and writers were compiling an "inventory" of dreams, or "an ongoing history of how people relate to their possibilities" (Yang 2017, 205).

Amidst a global resurgence of xenophobia, a tightening of national borders in all corners of the globe, it is time to consider alter-genealogies of the present and contemplate possible shared futures. Dreams can come unmoored from national imagined communities. Shared ethical and political commitments that reach across borders could liberate us from origin stories and reorient us toward emergent potentialities.

\section{References}

Andersen, K.G., A. Rambaut, W.I. Lipkin, E.C. Holmes, and R.F. Garry. 2020. The proximal origin of SARS-CoV-2. Nature Medicine 26: 450-452.

Benitez-Rojo, A. 1985. The repeating island. New England Review and Bread Loaf Quarterly 7(4): 430-452.

Blanchette, A. 2015. Herding species: Biosecurity, posthuman labor, and the American industrial pig. Cultural Anthropology 30(4): 640-669.

Chen, W., M. Yan, L. Yang, et al. 2005. SARS-associated coronavirus transmitted from human to pig. Emerging Infectious Diseases 11(3): 446-448.

Clifford, J. 1980. Book review: Orientalism. History and Theory 19(2): 204-223.

Cohen, J. 2020. Wuhan seafood market may not be source of novel virus spreading globally. Science 10(1126).

Foucault, M. 1977. Nietzsche, genealogy, history. In Language, Counter-Memory, Practice, edited by D.F. Bouchard, 139164. Ithaca: Cornell University Press.

Haraway, D. 2016. Staying with the trouble: Making kin in the Chthulucene. Durham: Duke University Press.

. 2008. When species meet. Minneapolis: University of Minnesota Press.

— 1988. Situated knowledges: The science question in feminism and the privilege of partial perspective. Feminist Studies 14(3): 575-600.

Helmreich, S. 2003. Trees and seas of information: Alien kinship and the biopolitics of gene transfer in marine biology and biotechnology. American Ethnologist 30(3): 341-359.

Huang, C., Y. Wang, X. Li, et al. 2020. Clinical features of patients infected with 2019 novel coronavirus in Wuhan, China. The Lancet 395(10223): 497-506.

Keck, F. 2020. Avian reservoirs: Virus hunters and birdwatchers in Chinese sentinel posts. Duke University Press.

Kirksey, E. 2015. Emergent ecologies. Durham: Duke University Press.

Kirksey, E. 2020. The emergence of COVID-19: A multispecies story. Anthropology Now 12(1): 11-16.

Lam, T.T., N. Jia, Y-W. Zhang. 2020. Identifying SARS-CoV2-related coronaviruses in Malayan pangolins. Nature 583(7815): 282-285.

Lowe, C. 2010. Viral clouds: Becoming H5N1 in Indonesia. Cultural Anthropology 25(4): 625-649.

Porter, N. 2019. Viral economies: Bird flu experiments in Vietnam. University of Chicago Press,.

Pratt, M.L. 1992. Imperial eyes: Travel writing and transculturation. London: Routledge,. 
Reardon, J., J. Metcalf, M. Kenney, and K. Barad. 2015. Science \& justice: The trouble and the promise. Catalyst: Feminism, Theory, Technoscience 1(1).

Rotman, B. 2008. Becoming beside ourselves: The alphabet, ghosts, and distributed human being. Durham: Duke University Press.

Said, E.W. 1979. Orientalism. New York: Vintage Books.

Wald, 2008. Contagious: Cultures, carriers, and the outbreak narrative. Durham: Duke University Press.

Xi, J. 2017. China dream speech: Full text of Xi Jinping's report at 19th CPC National Congress-China. China Daily, November 4. http://www.chinadaily.com.cn/china/ 19thcpcnationalcongress/2017-11/04/content_34115212. htm. Accessed 14 July 2021.

Xiao, X., Newman, C., Buesching, C., et al. 2021 Animal sales from Wuhan wet markets immediately prior to the COVID-19 pandemic. Scientific Reports 11(11898).
Yang, F. 2017. Temporality and Shenzhen Uubanism in the era of "China Dreams". Verge: Studies in Global Asias 3(1): 189-212.

Zhuang P., M. Zuo, and J. Wu. 2020. Wuhan pneumonia: How the search for the source of the mystery illness unfolded. South China Morning Post, January 7. https://www. scmp.com/news/china/society/article/3046233/wuhanpneumonia-how-search-source-mystery-illness-unfol ded. Accessed 8 September 2021.

Publisher's Note Springer Nature remains neutral with regard to jurisdictional claims in published maps and institutional affiliations. 